\title{
Radiological Impacts of Natural Radioactivity in Locally Produced Tobacco Products in Ibadan, Oyo State, Nigeria
}

\author{
Akinyose F. ${ }^{1 *}$., Tchokossa $\mathbf{P}^{1}$., Orosun M. $\mathbf{M}^{2}$., Oluyde S. $\mathbf{O}^{1}$., Umakha $\mathbf{M}^{1}$., Ochommadu \\ K. K ${ }^{1}$, Olaniyan T. $A^{1}$ and Ajibade O. $A^{1}$ \\ ${ }^{1}$ Department of Physics, Obafemi Awolowo University, Ile-Ife, Nigeria(*fisayo303@gmail.com) \\ ${ }^{2}$ Department of Physics, University of Ilorin, Ilorin, Nigeria.
}

\begin{abstract}
Radionuclides are found naturally in air, water and soil. They are even found in vegetation, consumer products and in human body. Everyone on the planet is exposed to some background level of ionizing radiation through external exposures that occurs as a result of irradiation, and internal exposures that occurs as a result of ingestion and inhalation. Studies have shown that tobacco contains minute quantities of radioisotopes from uranium and thorium-decay series which are radioactive and carcinogenic. Tobacco product increases both external and internal exposure due to these radioisotopes. In fact, tobacco products have been considered to be one of the most significant causes of lung cancer. Owing to the large-scale consumption of tobacco in Nigeria at the present time, locally produced tobacco products in Nigeria were collected from the market and the naturally-occurring ${ }^{238} \mathrm{U}$ and ${ }^{232} \mathrm{Th}$ decay series, as well as non-series decay ${ }^{40} \mathrm{~K}$ in these products were measured using $\gamma$-ray spectrometer. The radiological impacts of the radionuclides in these products were assessed from their specific activities. The average values of the absorbed dose rate were 19.72 and $17.59 \mathrm{nGy}^{-1}$ for snuff and cigarette products respectively. The average values of the effective doses due to daily inhalation of smoke by consumers from one wrap of snuff and one stick of cigarette products is 592.32 and $66.62 \mu \mathrm{Sv}$ $\mathrm{yr}^{-1}$ respectively. Similarly, the values of the radium equivalent activity index for snuff and cigarette samples were 40.95 and $38.95 \mathrm{~Bq} \mathrm{~kg}^{-1}$ respectively. Also the external radiation hazard index were 0.12 and 0.11 for snuff and cigarette samples respectively while the internal radiation hazard index were 0.17 and 0.15 for the two samples respectively. The average excess lifetime

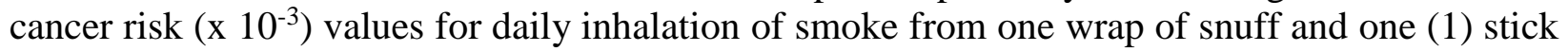
of cigarette were 2.07 and $0.23 \times 10^{-3}$ respectively. The estimated values of some of these parameters were found to be lower than the recommended limit by UNSCEAR (2000). However, the effective dose poses a serious health risk to addicted consumers of the product when three (3) or more wraps of snuff and one (1) or more packs of cigarette products are consumed daily. The mean excess lifetime cancer risks values estimated were also much higher than the recommended limits by UNSCEAR (2000). This then makes the risk of suffering cancer and other radiation injuries to be high.
\end{abstract}

Keywords: Radiological impacts, Tobacco, Cigarette, Snuff, Cancer, Radiation injury, Nigeria.

\section{INTRODUCTION}

Tobacco a green leafy plant in the kingdom Plantae is grown in warm climate. It belongs to the genus Nicotiana and species a Tabacum. After the leaves are harvested, they are then dried, ground and used in different ways: in the form of cigarette (the most consumed product in 
Nigeria), in pipe, or as cigar. They can also be chewed in the mouth (called smokeless tobacco or chewing tobacco) or sniffed through the nose (called snuff) (Madani et al., 2010). Tobacco has been well known with its nicotine content which makes the product addictive. More than 4,000 chemicals some of which are carcinogens have been isolated from tobacco. Hydrocarbons (aromatic and aliphatic), aldehydes, ketones, heavy metals including arsenic, non-radioactive lead, radionuclides among others) had been said to be present in tobacco (Reinskje et al., 2011; Thielen et al., 2008; Borgerding and Klus, 2005; Watson, 1985). This research work focused on the radioactive components found in tobacco and their likely contributions to health.

The source of radiation whether natural or artificial (man-made), it is a small dose of radiation or a large dose, there will still be some biological effects. Radiation causes ionizations of atoms which may affect molecules which in turns affect cells. Affected cells also affect the tissue which in turns affect organs and generally affect the whole body. Biological effects of radiation can occur as a result of exposure to high doses of radiation over short periods of time producing acute or short term effects (deterministic effect) or exposure to low doses of radiation over an extended period of time producing chronic or long term effects (stochastic effect). Exposure to low doses of radiation causes Genetic effect (effect suffered by the offspring of the individual exposed) and somatic effect. This is the effect suffered primarily by the exposed individual. Cancer is the primary result and it is sometimes called the carcinogenic effect (Hall, 2000).

Consumption of tobacco products may increase the internal intake and radiation dose due to radioisotopes present in them (Madani, et al., 2010; Papastefanou, 2009; Abd EL-Aziz et al., 2005; Khater, 2004; Takizawa, 1994; Colangelo et al., 1992). Though, this dose is low, but persisted consumption of these products makes it to be accumulated over an extended period of time in the body and can lead to chronic or long term effects (stochastic effect). It may not cause an immediate problem to the body organs but spread over a long period of time. Number of studies, inhalation of some naturally occurring radionuclides via smoking has been considered to be one of the most significant causes of lung cancer (Yasser and Khater, 2006). Tobacco products damage nearly every organ in the human body and accounts for some 30 per cent of all cancers death (WHO, 2008). Unlike vegetables that are always washed before consumption, tobacco leaves are directly dried in the tobacco curing process without washing and this makes tobacco product to retain almost all the contents present in the leaves (Barrera and Werusman, 1966). 
Tobacco products include the smoked and the smokeless tobacco. The smoked tobacco include: Bidis, Cigarettes, Cigars, Cigarillos, Little Cigars, Dissolvable tobacco, Electronic Cigarette or E- cigarette, Hookah, Kreteks and Pipe while the smokeless tobacco include the Snuff and the chewing or leaking tobacco. Among all these products, cigarettes and smokeless tobacco (snuff) are the products locally produced in Nigeria.

A cigarette is a combination of cured and finely cut tobacco with other additives (depending on the manufacturer) rolled into a paper wrapped cylinder. Most cigarettes have filters on side placed in the mouth. Studies have proven that smoking cigarettes causes cancers of the bladder, oral cavity, pharynx, larynx (voice box), esophagus, cervix, kidney, lung, pancreas, and stomach, and causes acute myeloid leukemia. It also causes heart disease and stroke (NIH, 1993; Singh and Nikelani, 1976; Khater, 2004; Papastefanou, 2009; Madani et al., 2010;Jibiri and Biere, 2011;Landsberger et al., 2015).Among two main types of smokeless tobacco, snuff and chewing or leaking tobacco, chewing tobacco is mainly the raw leaves while snuff is pulverized tobacco leaves that are in sachets. Snuffs locally made in Nigeria, wrapped in paper or nylon and usually inhaled (sniffed) through the nose. Smokeless tobacco has a significant health risk and is not a safe substitute for smoking cigarettes (Desalu et al., 2010; Critchley et al., 2003; NIH, 1993).

The carcinogenic effects and some other diseases related to these products may be as a result of the radioactive elements (Tso et al., 1966) that may be present on the leaves before the leaves are processed to products. All methods of tobacco consumption results in varying quantities of radiation to be absorbed into the consumers bloodstream which can cause radiation injuries such as cancer, ulcer, leukemia and many other diseases over time (Ponte, 1986). Thus many countries set a minimum smoking age, regulating the purchase and use of tobacco products.

The main routes of radionuclide in tobacco are the fertilizer that farmers use to increase the size of their tobacco crops and trichomes, a sticky, hair-like projection that thickly cover both sides of tobacco leaves (Jibiri and Biere 2011). Rain cannot wash them away and their presence in tobacco depends on the tobacco origin which depends on how much fertilizer is used and the natural level of uranium and radium in the soil where the tobacco is grown (Jibiri and Fasae, 2012; Papastefanou 2009; Khater, 2004, Martell, 1974; Abd EL-Aziz et al., 2005).

Although not everyone who uses tobacco will get cancer and not everyone that gets cancer uses tobacco, but its consumption over time increases the risk. Though, it contains low concentration of radionuclides, its consumption over time could lead to high concentrations in various organs 
of the body and cause disease. Present paper tries to assess the risk associated with the consumption of tobacco products due to these naturally occurring radionuclides.

\section{MATERIALS AND METHOD}

\subsection{Sample Collection}

Smoked (cigarette) and smokeless (snuff) tobacco products were obtained from Agbeni market in Ibadan, Nigeria. This market is a wholesalers market popularly known as the "mother of markets" in the city of Ibadan, Oyo state, Nigeria. Twelve (12) cigarette samples comprising six (6) packets each of different brands and two (2) snuff samples were bought a piece from two different shops in the market. At the point of collection of the samples, they were thoroughly mixed together to represent a sample from each shop and then carefully labeled and placed in separate polythene bags to avoid cross contamination. The descriptions of the various samples are shown in table 1 and the location map of the study area, Oyo State in figure 1.

\subsection{Sample Preparation}

The samples were dried at of $105^{\circ} \mathrm{C}$ in a temperature controlled oven until there was no detectable change in the mass of the samples. Cigarette samples were then thoroughly ground and pulverized to obtain a powder form like snuff samples. Each sample was weighed and sealed for at least 28 days in a clean and uncontaminated air tight radon impermeable plastic container. This was done in order to allow radon and its short-lived progenies to reach secular radioactive equilibrium prior to gamma spectroscopy.

\subsection{Radioactivity Measurement}

The detector used for the radioactivity measurements is a lead-shielded $76 \mathrm{~mm} \times 76 \mathrm{~mm} \mathrm{NaI}(\mathrm{Tl})$ detector crystal (Model No. 802 series, Canberra Inc.) coupled to a Canberra Series 10 plus Multichannel Analyzer (MCA) (Model No.1104) through a preamplifier. It is located at Center

for Energy Research and Development (CERD), Obafemi Awolowo University, Ile-Ife, Osun state, Nigeria. Its resolution is considered adequate to distinguish the gamma ray energies of interest in this study. Each sealed samples was placed on the shielded $\mathrm{NaI}(\mathrm{Tl})$ detector and counted for 18,000s. The samples containers have the same geometry as that of the IAEA reference sample material. The IAEA-375 soil reference material was used. An empty container of the same geometry and dimension was counted for the same counting time of 18,000 s to determine the background distribution spectrum. 
Table 1. Tobacco Products Bought from Agbeni Market, Ibadan.

\begin{tabular}{|c|c|c|c|c|c|c|}
\hline S.No & $\begin{array}{l}\text { Sample } \\
\text { ID }\end{array}$ & Samples name & $\begin{array}{l}\text { mass of } \\
\text { fresh } \\
\text { tobacco } \\
\text { product }(g)\end{array}$ & $\begin{array}{l}\text { Mass after } \\
\text { sieving of } \\
\text { dried tobacco } \\
\text { product }(\mathrm{g})\end{array}$ & Longitude & Latitude \\
\hline \multicolumn{7}{|c|}{ SNUFF } \\
\hline 1 & $\mathrm{AFC1}$ & Snuff A & 106.1 & 105.5 & $3^{\circ} 53^{\prime} 25.05^{\prime \prime} \mathrm{E}$ & $7^{\circ} 22^{\prime} 48.52^{\prime \prime} \mathrm{N}$ \\
\hline 2 & AFC2 & Snuff B & 109.5 & 108.8 & $3^{\circ} 53^{\prime} 25.00^{\prime \prime} \mathrm{E}$ & $7^{\circ} 22^{\prime} 48.23^{\prime \prime} \mathrm{N}$ \\
\hline \multicolumn{7}{|c|}{ CIGARETTE } \\
\hline 1 & AFD1 & Pallmall red A & 108.9 & 107.7 & $3^{\circ} 53^{\prime} 25.10^{\prime \prime} \mathrm{E}$ & $7^{\circ} 22^{\prime} 48.31^{\prime \prime} \mathrm{N}$ \\
\hline 2 & AFD2 & Pallmall red B & 105.2 & 103.4 & $3^{\circ} 53^{\prime} 25.17^{\prime \prime} \mathrm{E}$ & $7^{\circ} 22^{\prime} 48.34^{\prime \prime} \mathrm{N}$ \\
\hline 3 & AFE1 & London Menthol A & 97.7 & 94.8 & $3^{\circ} 53^{\prime} 25.10^{\prime \prime} \mathrm{E}$ & $7^{\circ} 22^{\prime} 48.31^{\prime \prime} \mathrm{N}$ \\
\hline 4 & AFE2 & London Menthol B & 98.9 & 96.0 & $3^{\circ} 53^{\prime} 25.17^{\prime \prime}$ & $7^{\circ} 22^{\prime} 48.34^{\prime \prime} \mathrm{N}$ \\
\hline 5 & AFF1 & London King size A & \begin{tabular}{|l|}
111.4 \\
\end{tabular} & 110.8 & $3^{\circ} 53^{\prime} 25.10^{\prime \prime}$ & $7^{\circ} 22^{\prime} 48.31^{\prime \prime} \mathrm{N}$ \\
\hline 6 & AFF2 & London King size B & 115.2 & 114.6 & $3^{\circ} 53^{\prime} 25.17^{\prime \prime}$ & $7^{\circ} 22^{\prime} 48.34^{\prime \prime} \mathrm{N}$ \\
\hline 7 & AFG1 & Royal standard A & 93.1 & 91.2 & $3^{\circ} 53^{\prime} 25.10^{\prime \prime}$ & $7^{\circ} 22^{\prime} 48.31^{\prime \prime} \mathrm{N}$ \\
\hline 8 & AFG2 & Royal standard B & 94.7 & 93.5 & $3^{\circ} 53^{\prime} 25.17^{\prime \prime}$ & $7^{\circ} 22^{\prime} 48.34^{\prime \prime} \mathrm{N}$ \\
\hline 9 & AFH1 & Aspen A & 101.7 & 99.2 & $3^{\circ} 53^{\prime} 25.10^{\prime \prime}$ & $7^{\circ} 22^{\prime} 48.31^{\prime \prime} \mathrm{N}$ \\
\hline 10 & $\mathrm{AFH} 2$ & Aspen B & 102.1 & 100.7 & $3^{\circ} 53^{\prime} 25.17^{\prime \prime}$ & $7^{\circ} 22^{\prime} 48.34^{\prime \prime} \mathrm{N}$ \\
\hline 11 & AFI1 & Pallmall green $\mathrm{A}$ & 104.2 & 102.6 & $3^{\circ} 53^{\prime} 25.10^{\prime \prime}$ & $7^{\circ} 22^{\prime} 48.31^{\prime \prime} \mathrm{N}$ \\
\hline 12 & AFI2 & Pallmall green B & 108.5 & 107.2 & $3^{\circ} 53^{\prime} 25.17^{\prime \prime}$ & $7^{\circ} 22^{\prime} 48.34^{\prime \prime} \mathrm{N}$ \\
\hline
\end{tabular}

Note: The filters in the cigarette samples have been removed, Average of $0.86 \mathrm{~g}$ per mass of fresh tobacco is used in one cigarette.

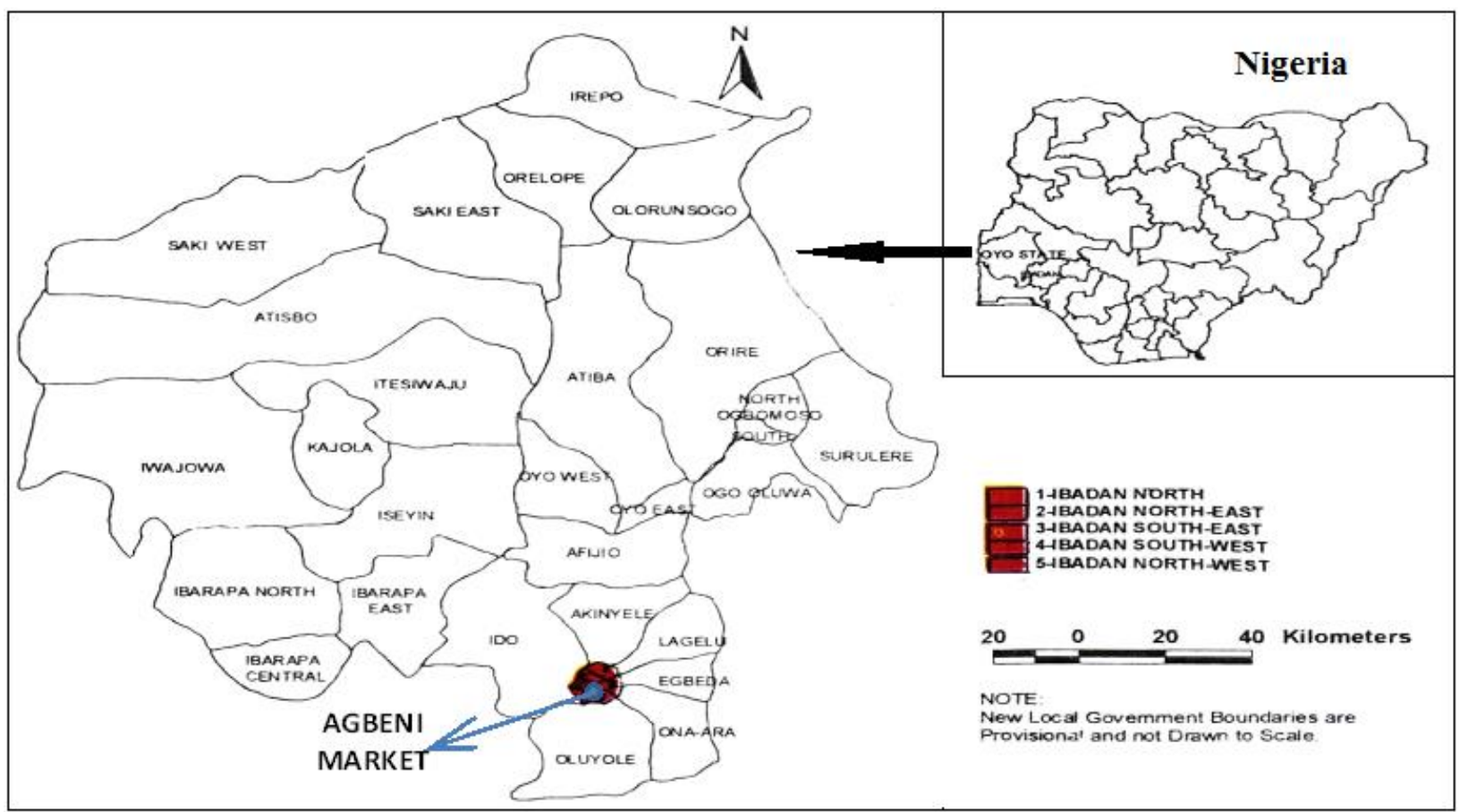

Figure 1. Map of Oyo State showing the study area " $8.1196^{\circ} \mathrm{N}, 3.4196^{\circ} \mathrm{E}$ " (Note: New local government boundaries are provisional and not drawn to scale). 
The choice of radionuclides to be detected was predicated on the fact that the $\mathrm{NaI}(\mathrm{Tl})$ detector used in the present study has a modest energy resolution. Hence, the photons emitted by them would only be sufficiently discriminated if their emission probability and their energy were high enough, and the surrounding background continuum is low enough. Therefore, the activity concentration of ${ }^{214} \mathrm{Bi}$ (determined from its $1120 \mathrm{keV}$ and $609 \mathrm{keV} \gamma$-ray peaks) were chosen to provide an estimate of ${ }^{226} \mathrm{Ra}\left({ }^{238} \mathrm{U}\right)$ in the samples, while that of the daughter radionuclide ${ }^{228} \mathrm{Ac}$ determined from its $911 \mathrm{keV} \gamma$-ray peak was chosen as an indicator of ${ }^{232} \mathrm{Th} .{ }^{40} \mathrm{~K}$ was determined by measuring the $1460 \mathrm{keV} \gamma$-rays emitted during its decay. The net area under the corresponding peaks in the energy spectrum was computed by subtracting counts due to compton scattering of higher peaks and other background sources from the total area of the peaks. From the net area, the activity concentrations in the samples were obtained using equation 1 below:

$$
C=\frac{A}{\varepsilon M_{s} P_{\gamma} t_{c}}
$$

Where $\mathrm{A}=$ the net area of the peak,

$\varepsilon=$ efficiency of the detector for radionuclide $\mathrm{n}$;

$\mathrm{M}_{\mathrm{s}}=$ dried mass of ashed sample for measurement in $\mathrm{kg}$;

$\mathrm{P}_{\gamma}=$ gamma emission probability (or branch ratio); and

$\mathrm{t}_{\mathrm{c}}=$ counting time

\section{RESUTS AND DISCUSSION}

Table 2 and figures 2 to5 presents the activity concentrations and all the radiological impact parameters estimated from the determined activity concentration in the tobacco products analyzed. This was done in order to assess the possible health hazard posed by these products.

\subsection{Radionuclides Concentration}

The activity concentration of the radionuclides detected is presented in table 2 . All the radionuclides detected and quantified came from the naturally-occurring ${ }^{238} \mathrm{U}$ and ${ }^{232} \mathrm{Th}$ decay series, as well as non-series ${ }^{40} \mathrm{~K}$. As could be observed from the table, the specific activity concentration of ${ }^{40} \mathrm{~K},{ }^{238} \mathrm{U}$ and ${ }^{232} \mathrm{Th}$ for snuff products ranged between $64.28 \pm 20.43$ and 74.38 $\pm 25.20 \mathrm{~Bq} \mathrm{~kg}^{-1}$ (with an average of $69.33 \pm 22.82 \mathrm{~Bq} \mathrm{~kg}^{-1}$ ), $9.45 \pm 3.88$ and $25.36 \pm 7.51 \mathrm{~Bq} \mathrm{~kg}^{-1}$ (with an average of $17.41 \pm 5.70 \mathrm{~Bq} \mathrm{~kg}^{-1}$ ), $10.28 \pm 4.37$ and $18.81 \pm 7.22 \mathrm{~Bq} \mathrm{~kg}^{-1}$ (with an average of $14.55 \pm 5.80 \mathrm{~Bq} \mathrm{~kg}^{-1}$ ) respectively. 
For cigarette products, the specific activity concentration of ${ }^{40} \mathrm{~K},{ }^{238} \mathrm{U}$ and ${ }^{232} \mathrm{Th}$ ranged from $40.13 \pm 14.23$ to $57.53 \pm 20.13 \mathrm{~Bq} \mathrm{~kg}^{-1}$ (with an average of $48.37 \pm 15.78 \mathrm{~Bq} \mathrm{~kg}^{-1}$ ), $8.91 \pm 3.41$ to $28.56 \pm 7.69 \mathrm{~Bq} \mathrm{~kg}^{-1}$ (with an average of $17.52 \pm 5.73 \mathrm{~Bq} \mathrm{~kg}^{-1}$ ) and $4.90 \pm 1.49$ to $19.39 \pm 8.13$ $\mathrm{Bq} \mathrm{kg}^{-1}$ (with an average of $12.39 \pm 4.50 \mathrm{~Bq} \mathrm{~kg}^{-1}$ ) respectively.

From the result above, it can be noticed that the radioactivity in snuff products was a little bit higher than that of the cigarette products. It was also noticed that the radioactivity content varies within the same brands of cigarette and also with different brands. This may be attributed to the geographic region where the tobacco (raw material) is grown, the fineness of the tobacco cut, different manufacturing procedures and age of the tobacco product (Skwarzec et al., 2001a; Watson, 1985).

\subsection{Annual Effective Dose $\mathrm{E}\left(\mu \mathrm{Sv} \mathrm{yr}^{-1}\right)$ from Tobacco Products}

The effective dose is a quantity that takes the damaging properties of different types of radiation into account. Absorbed dose tells us the energy deposit in a small volume of tissue and effective dose addresses the impact a type of radiation will have in all organs of the body. It is the tissueweighted sum of the equivalent doses in all specified tissues and organs of the body and represents the stochastic health risks to the whole body. It takes into account the type of radiation and the nature of each organ or tissue being irradiated, and enables summation of organ doses due to varying levels and types of radiation. Annual effective dose is the sum of the effective dose over a year.

a) The annual effective dose $\left(\mu \mathrm{Sv} \mathrm{y}^{-1}\right)$ due to inhalation of snuff products

The annual effective dose due to inhalation of snuff products was calculated using equation 2 (Papastefanou, 2009; Khater, 2004):

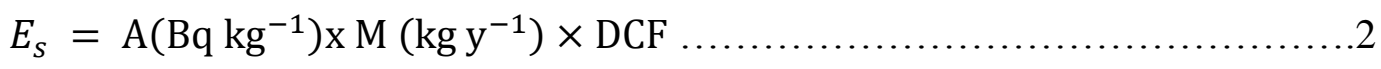

b) The annual effective dose $\left(\mu \mathrm{Sv}^{-1}\right)$ due to inhalation of cigarette products

About $75 \%$ of the radioisotope in the cigarette tobacco will be contained in the cigarette smoke, which is partially inhaled and deposited in body tissues. $25 \%$ will also be retained in the cigarette filter and ash (Landsberger et al., 2015; Papastefanou, 2009; Khater, 2004; Skwarzec et al., 2001b). Therefore, the annual effective dose from cigarette smoke was calculated using equation 3.

$$
E_{c}=0.75 \times E_{S}
$$


Table 2.Activity concentration of radionuclides and radiological impact $\left(\mathrm{Bq} \mathrm{kg}^{-1}\right)$ in tobacco products.

\begin{tabular}{|c|c|c|c|c|c|c|c|c|c|c|}
\hline S.No & ID & $K-40\left(B q k g^{-1}\right)$ & $U-238\left(B q k g^{-1}\right)$ & Th-232(Bq/kg) & $D\left(n G y h^{-1}\right)$ & $E\left(\mu S v y^{-1}\right)$ & $\operatorname{ELCR}\left(x 10^{-1}\right)$ & $E^{*}$ & ELCR* & $\operatorname{Ra}_{e q}\left(B q \boldsymbol{k g}^{-1}\right)$ \\
\hline \multicolumn{11}{|c|}{ SNUFF } \\
\hline 1 & $\mathrm{AFC1}$ & $64.28 \pm 20.43$ & $25.36 \pm 7.51$ & $10.28 \pm 4.37$ & 20.61 & 450.47 & 1.58 & NA & NA & 42.81 \\
\hline \multirow[t]{2}{*}{2} & $\mathrm{AFC} 2$ & $74.38 \pm 25.20$ & $9.45 \pm 3.88$ & $18.81 \pm 7.22$ & 18.83 & 734.17 & 2.57 & NA & NA & 39.10 \\
\hline & MEAN & $69.33 \pm 22.82$ & $17.41 \pm 5.70$ & $14.55 \pm 5.80$ & 19.72 & 592.32 & 2.07 & NA & NA & 40.95 \\
\hline \multicolumn{11}{|c|}{ CIGARETTE } \\
\hline 3 & AFD1 & $49.81 \pm 12.47$ & $28.56 \pm 7.69$ & $9.49 \pm 3.45$ & 21.00 & 111.38 & 0.39 & 55.69 & 0.19 & 45.97 \\
\hline \multirow[t]{2}{*}{4} & AFD2 & $42.52 \pm 15.69$ & $14.43 \pm 5.18$ & $11.04 \pm 3.61$ & 15.11 & 118.05 & 0.41 & 59.03 & 0.21 & 33.49 \\
\hline & MEAN & $46.17 \pm 14.08$ & $21.50 \pm 6.44$ & $10.27 \pm 3.53$ & 18.06 & 114.72 & 0.40 & 57.36 & 0.20 & 39.73 \\
\hline 5 & AFE1 & $56.83 \pm 19.95$ & $19.04 \pm 6.49$ & $8.34 \pm 3.42$ & 16.20 & 94.18 & 0.33 & 47.09 & 0.16 & 35.34 \\
\hline \multirow[t]{2}{*}{6} & AFE2 & $46.01 \pm 16.01$ & $17.87 \pm 5.98$ & $7.18 \pm 2.52$ & 14.51 & 81.98 & 0.29 & 40.99 & 0.14 & 31.68 \\
\hline & MEAN & $51.42 \pm 17.98$ & $18.46 \pm 6.24$ & $7.76 \pm 2.97$ & 15.36 & \begin{tabular}{|l|}
88.08 \\
\end{tabular} & 0.31 & 44.04 & 0.15 & 33.51 \\
\hline 7 & AFF1 & $40.13 \pm 14.23$ & $11.78 \pm 4.68$ & $4.90 \pm 1.49$ & 10.08 & 55.70 & 0.19 & 27.85 & 0.10 & 21.88 \\
\hline \multirow[t]{2}{*}{8} & AFF2 & $44.32 \pm 13.12$ & $13.85 \pm 5.82$ & $6.78 \pm 2.76$ & 12.34 & 75.56 & 0.26 & 37.78 & 0.13 & 26.96 \\
\hline & MEAN & $42.23 \pm 13.69$ & $12.82 \pm 5.25$ & $5.84 \pm 2.13$ & 11.21 & 65.63 & 0.23 & 32.82 & 0.11 & 24.42 \\
\hline 9 & AFG1 & $53.62 \pm 19.84$ & $12.77 \pm 5.79$ & $18.22 \pm 6.81$ & 19.14 & 188.06 & 0.66 & 94.03 & 0.33 & 42.95 \\
\hline \multirow[t]{2}{*}{10} & AFG2 & $57.53 \pm 20.13$ & $28.50 \pm 6.88$ & $15.34 \pm 5.19$ & 24.83 & 169.21 & 0.59 & 84.61 & 0.30 & 54.87 \\
\hline & MEAN & $55.58 \pm 19.99$ & $20.64 \pm 6.34$ & $16.78 \pm 6.00$ & 21.99 & 178.63 & 0.63 & 89.32 & 0.31 & 48.91 \\
\hline 11 & AFH1 & $44.14 \pm 13.02$ & $23.06 \pm 7.31$ & $12.57 \pm 3.43$ & 20.09 & 138.47 & 0.48 & 69.24 & 0.24 & 44.43 \\
\hline \multirow[t]{2}{*}{12} & AFH2 & $53.26 \pm 17.13$ & $8.91 \pm 3.41$ & $19.08 \pm 7.87$ & 17.86 & 194.20 & 0.68 & 97.10 & 0.34 & 40.30 \\
\hline & MEAN & $48.70 \pm 15.08$ & $15.99 \pm 5.36$ & $15.83 \pm 5.65$ & 18.97 & \begin{tabular}{|l|}
166.34 \\
\end{tabular} & 0.58 & 83.14 & 0.29 & 42.36 \\
\hline 13 & AFI1 & $42.70 \pm 12.31$ & $16.49 \pm 5.31$ & $19.39 \pm 8.13$ & 21.11 & 201.90 & 0.71 & 100.95 & 0.35 & 47.51 \\
\hline \multirow[t]{3}{*}{14} & AFI2 & $49.57 \pm 15.35$ & $14.93 \pm 4.13$ & $16.28 \pm 5.31$ & 18.80 & 170.19 & 0.60 & 85.10 & 0.30 & 42.03 \\
\hline & MEAN & $46.14 \pm 13.83$ & $15.71 \pm 4.72$ & $17.84 \pm 6.72$ & 19.95 & 186.05 & 0.65 & 93.03 & $\mathbf{0 . 3 3}$ & 44.77 \\
\hline & OCM & $48.37 \pm 15.78$ & $17.52 \pm 5.73$ & $12.39 \pm 4.50$ & 17.59 & 133.24 & 0.47 & 66.62 & 0.23 & 38.95 \\
\hline
\end{tabular}

Note: $\mathrm{E}^{*} \& \mathrm{ELCR}^{*}$-annual effective doses and excess lifetime cancer risks for smokers inhaling $50 \%$ of cigarette smoke respectively; OCM = Overall cigarette mean;

$\mathrm{NA}=$ Not applicable to snuff products. 
At least $50 \%$ of the cigarette smoke was said to be inhaled by primary smoker (Khater, 2004; Skwarzec et al., 2001b). Therefore, the annual effective dose inhaled from cigarette smoke by primary smokers was calculated using equation 4.

$$
E_{c p}=0.5 \times E_{c}
$$

Where, $E_{s}$ is the annual effective dose for snuff;

$E_{\mathrm{c}}$ is the annual effective dose for cigarette smoke;

$\mathrm{E}_{\mathrm{cp}}$ is the annual effective dose due to inhalation of cigarette smoke by primary smokers;

A is the activity concentration of radionuclide;

$\mathrm{M}$ is the consumption rate per year and DCF is the standard dose conversion factor.

The most recent dose conversion coefficients for the case of inhalation for adults are $2.9 \times 10^{-6}$, $4.5 \times 10^{-5}$, and $2.1 \times 10^{-9} \mathrm{~Sv} \mathrm{~Bq}^{-1}$ for ${ }^{238} \mathrm{U},{ }^{232} \mathrm{Th}$ and ${ }^{40} \mathrm{~K}$ respectively (ICRP, 2012).

Locally made snuffs in Nigeria are sold in wrapping papers or nylons. Average mass of one (1) wrap of snuff is $2.3 \mathrm{~g}$ and that of fresh tobacco per stick of cigarette is $0.86 \mathrm{~g}$. Therefore, the annual consumption rate of consuming one (1) wrap and one (1) stick of snuff and cigarette daily were estimated to be: 0.840 and $0.314 \mathrm{~kg} \mathrm{y}^{-1}$ respectively.

$$
\begin{aligned}
& M_{s}=1 \text { (snuff/day) X } 365 \text { (days in a year) X } 2.3 \mathrm{~g} / \mathrm{snuff}=0.840 \mathrm{~kg} \mathrm{y}^{-1} \\
& M_{\mathrm{c}}=1 \text { (cigarette/day) X } 365 \text { (days in a year) X } 0.86 \mathrm{~g} / \text { cigarette }=0.314 \mathrm{~kg} \mathrm{y}^{-1}
\end{aligned}
$$

Where, $M_{s}$ and $M_{c}$ are annual masses of tobacco per snuff and cigarette consumed, respectively. The values of the annual effective dose due to sniffing of one wrap of snuff daily is ranged between 450.47 and $734.17 \mu \mathrm{Sv} \mathrm{yr}^{-1}$, with an average value of $592.32 \mu \mathrm{Sv} \mathrm{yr}{ }^{-1}$. Also, the annual values of the annual effective dose of the smoke from one stick of cigarette daily is ranged from 55.70 to $201.90 \mu \mathrm{Sv} \mathrm{yr}^{-1}$ with an average of $133.24 \mu \mathrm{Sv} \mathrm{yr}^{-1}$. Similarly, the annual effective dose for primary smokers inhaling 50\% of the cigarette smoke (Khater 2004; Skwarzec et al., 2001b) from one (1) stick of cigarette daily ranged from 27.85 to $100.95 \mu \mathrm{Sv} \mathrm{yr}^{-1}$ with an average of $66.62 \mu \mathrm{Sv} \mathrm{yr}^{-1}$. This dose of respondent not smoking more than 1 cigarette in a day was low when compared with the average worldwide exposure to natural radiation sources which is 2400 $\mu \mathrm{Sv} \mathrm{y}^{-1}$ and especially the part due to inhalation which is $1260 \mu \mathrm{Sv} \mathrm{y}^{-1}$ (UNSCEAR, 2000).

The effective doses were found to be higher in snuff than in cigarettes mainly due to the absence of filter in snuff. All the calculated values were found to be lower than the recommended limit of $1260 \mu \mathrm{Sv} \mathrm{y}^{-1}$ (UNSCEAR, 2000), and hence do not pose serious health risk. However, it is to be noticed that all the calculated values above were for one wrap of snuff and one stick of cigarette. 
It will be an under estimation to consume just one wrap of snuff and one stick of cigarette daily for the addicted consumers as tobacco contains nicotine which makes the product to be addictive. In fact, according to the Newspaper "Sun" (2017), 4.5million Nigerians consumes $\sim 20$ billion cigarettes yearly and these products are readily available and are not expensive.

Therefore, the dose received from cigarette and snuff product increases as consumption rate increases. Consuming three wraps of snuff daily will result in a mean annual effective dose of $1776.96 \mu \mathrm{Sv} \mathrm{y}^{-1}$ and smoking one pack of cigarette daily will result in mean annual effective doses of 2664.80 and $1332.41 \mu \mathrm{Sv} \mathrm{y}^{-1}$ for $100 \%$ of the smoke and $50 \%$ of the smoke(for primary smoker)respectively. These values are higher than the recommended limit of $1260 \mu \mathrm{Sv} \mathrm{y}{ }^{-1}$ (UNSCEAR 2000). This therefore increases the internal intake of ${ }^{40} \mathrm{~K},{ }^{238} \mathrm{U}$, and ${ }^{232} \mathrm{Th}$ which are gamma emitters. When these radionuclides are inhaled, they are deposited in the lung tissues and other critical organs within the body; which then contributes to an increase in the internal radiation dose and in the number of lung cancer and other related radiation diseases incidences observed among consumers of tobacco products.

\subsection{Radium Equivalent activity Index (Raeq) for Tobacco Products}

This allows a single index or number to describe the gamma output from different mixtures of ${ }^{238} \mathrm{U},{ }^{232} \mathrm{Th}$ and ${ }^{40} \mathrm{~K}$ in a material. It was calculated using equation 5 by UNSCEAR (2000):

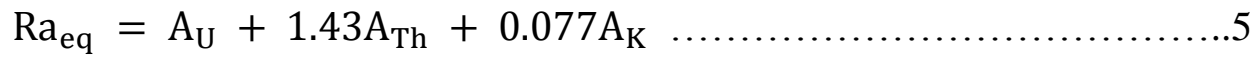

Where, $A_{U}, A_{T h}$ and $A_{K}$ are radioactivity concentrations in $\mathrm{Bq} \mathrm{kg}^{-1}$ of ${ }^{238} \mathrm{U},{ }^{232} \mathrm{Th}$ and ${ }^{40} \mathrm{~K}$ respectively.

The values of the radium equivalent activity index, $\mathrm{Ra}_{\mathrm{eq}}\left(\mathrm{Bq} \mathrm{kg}^{-1}\right)$ for tobacco product is ranging between 39.10 and $42.81 \mathrm{~Bq} \mathrm{~kg}^{-1}$ with an average of $40.95 \mathrm{~Bq} \mathrm{~kg}^{-1}$ for snuff and is ranging from 21.88 to $54.87 \mathrm{~Bq} \mathrm{~kg}^{-1}$ with an average of $38.95 \mathrm{~Bq} \mathrm{~kg}^{-1}$ for cigarette products. These values were found to be lower than the recommended limit i.e.370 $\mathrm{Bq} \mathrm{kg}^{-1}$ (UNSCEAR, 2000). Hence, the products do not pose a serious health risk but the radioactivity contents have to be monitored not only because of the persistent usage of phosphate fertilizer by farmers on soils where the raw material (tobacco leaf) is produced from but also for its long term effect, due to accumulation.

\subsection{Excess Lifetime Cancer Risk (ELCR) for Tobacco Products}

The excess lifetime cancer risk (ELCR) is calculated using the below mentioned equation (Avwiri et al., 2014):

$$
\mathrm{ELCR}=\mathrm{AEDE} \times \mathrm{DL} \times \mathrm{RF}
$$

(C) CNCS, Mekelle University 
Where, AEDE is the annual equivalent dose equivalent,

DL is the average duration of life (estimated to 70 years),

$\mathrm{RF}$ is the Risk Factor $\left(\mathrm{Sv}^{-1}\right)$, i.e. fatal cancer risk per Sievert.

For stochastic effects, ICRP uses RF as 0.05 for public (Avwiri et al., 2014). Average value of ELCR is given as $0.2 \times 10^{-3}$ (UNSCEAR, 2008; UNSCEAR,2000). The estimated values of the excess life time cancer risk $\left(\times 10^{-3}\right)$ from one (1) wrap of snuff daily ranged between 1.00 and 1.65 with an average of 1.32 . Similarly, it ranged from 0.20 to 0.71 with an average of 0.47 for cigarette smoke from one (1) stick. The excess lifetime cancer risk ELCR (x 10 $\left.0^{-3}\right)$ for smokers inhaling 50\% of the cigarette smoke (Skwarzec et al., 2001b; Khater, 2004) from one (1) stick of cigarette daily ranged between 0.10 and 0.36 with an average of 0.24 .

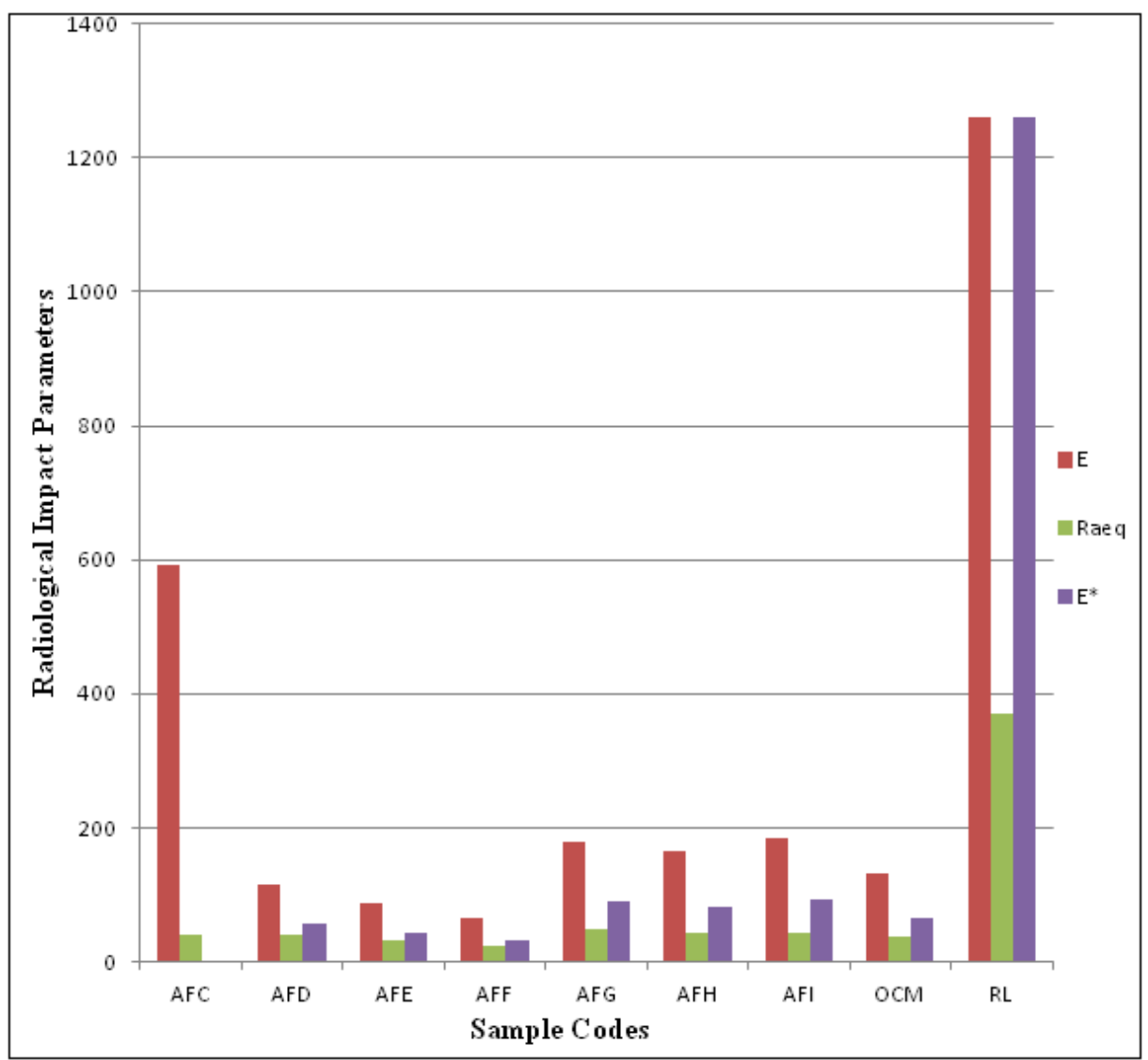

Figure 2. Radiological impact parameters for tobacco products(UNSCEAR, 2000). (Note: D is the absorbed dose rate; $\mathrm{E}$ is the equivalent dose for $100 \%$ of the smoke: Raeq is the radium equivalent activity index and $\mathrm{E}^{*}$ is the equivalent dose for $50 \%$ of the smoke inhaled by primary smoker; and RL is the world average values). 


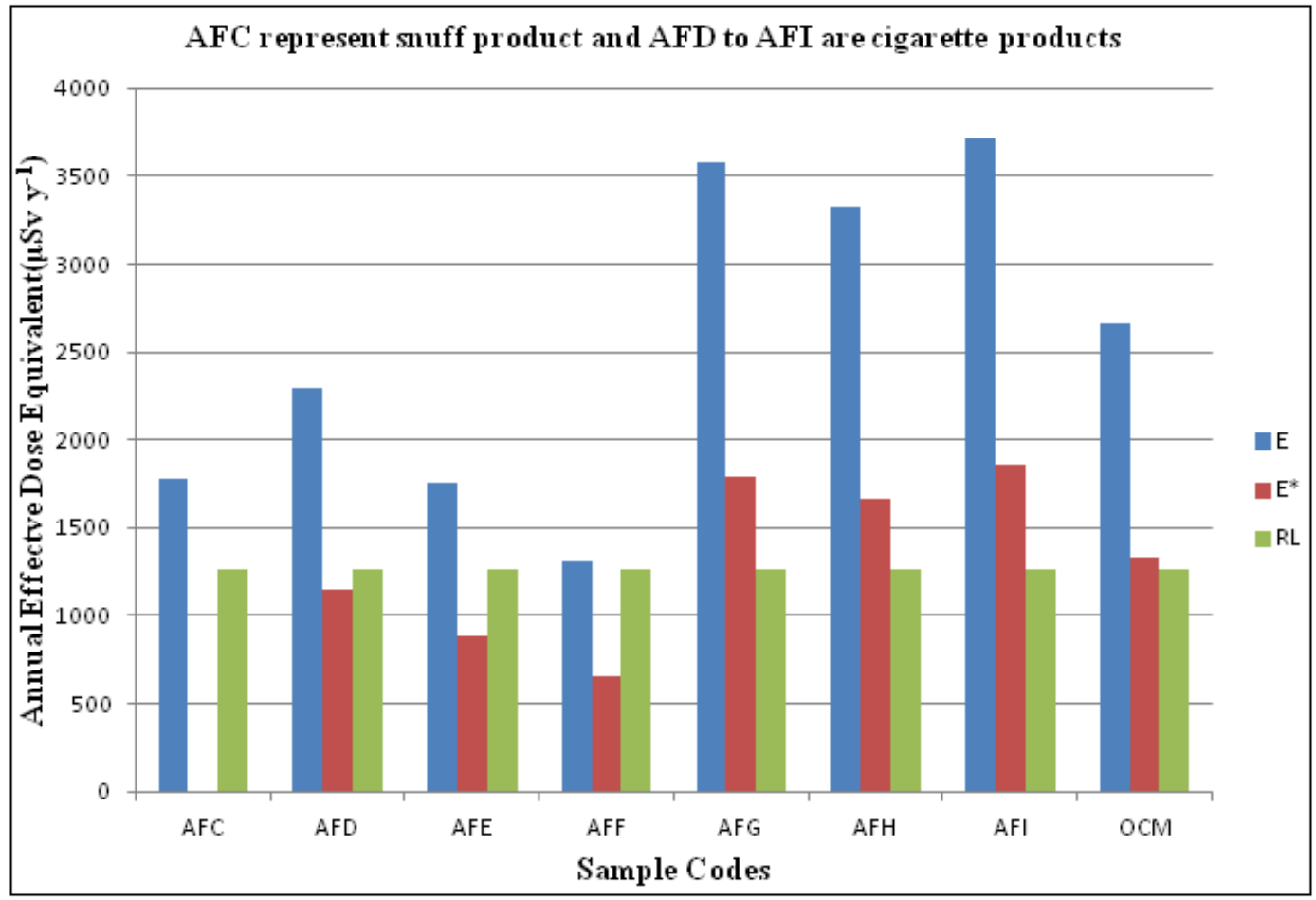

Figure 3. Annual effective doses equivalent $\left(\mu \mathrm{Sv} \mathrm{y}^{-1}\right)$ for Sniffing 3 wraps of snuff (AFC) and 1 pack of cigarette daily (AFD - AFI).

Note: RL is the recommended limit by UNSCEAR (2000); E is the annual effective dose for sniffing 3 wraps of snuff daily (AFC) and annual effective dose for inhaling $100 \%$ of the smoke from 1 pack of cigarette daily (AFD - AFI); $\mathrm{E}^{*}$ is the annual effective dose received by primary smoker inhaling 50\% of smoke from 1 pack of cigarette daily (AFD - AFI); OCM is the overall mean of the annual effective received from inhaling $50 \%$ (for primary smokers) and $100 \%$ (all the smoke) of the smoke from cigarette.

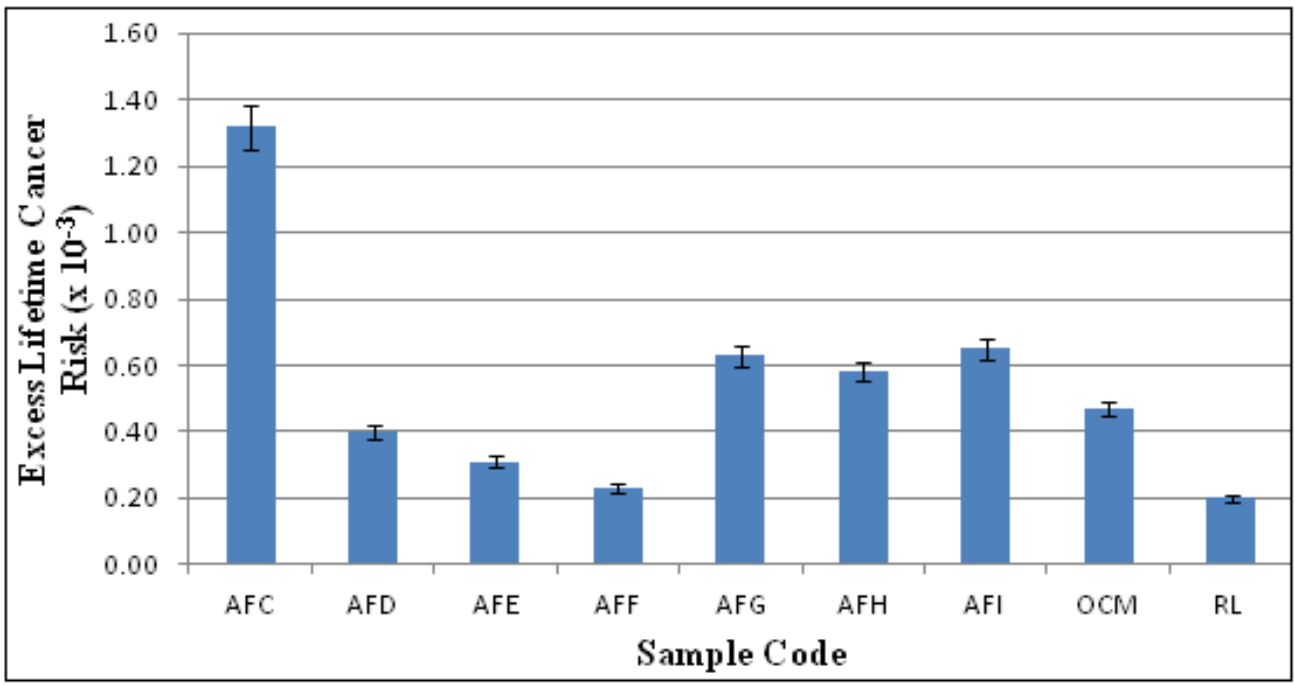

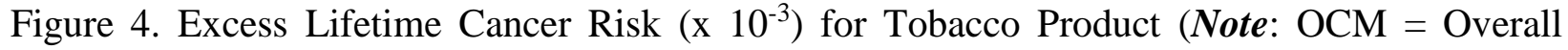
cigarette mean; RL = Recommended limit by UNSCEAR (2000)). 


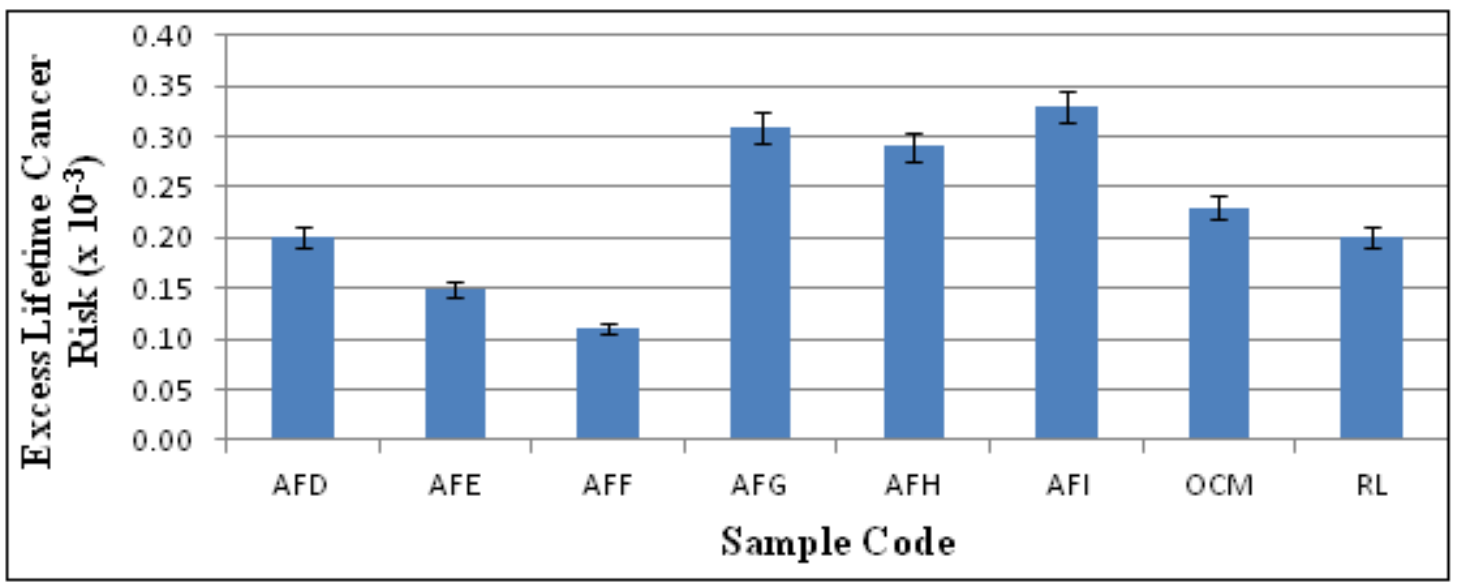

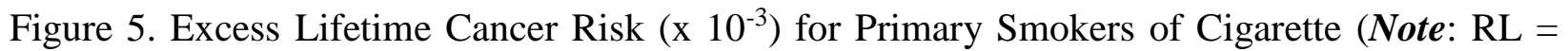
recommended limit by UNSCEAR (2000); OCM = Overall cigarette mean).

It is important to note that almost all the values calculated were higher than the recommended limit of $0.2 \times 10^{-3}$ (UNSCEAR, 2000) and these values were just for one (1) wrap of snuff and one (1) stick of cigarette daily. Estimating the ELCR for the addicted consumers will be extremely high. This poses a serious cancer risk to all the consumers and even the passive smokers in the environment.

\section{CONCLUSION}

Assessment of the natural radioactivity content and the radiological risk in locally produced tobacco derived products in Ibadan, Nigeria has been carried out using a sodium iodide (NaI(Tl)) detector.

The radionuclides detected and quantified in this study came from the naturally-occurring ${ }^{238} \mathrm{U}$ and ${ }^{232} \mathrm{Th}$ decay series, as well as non-series ${ }^{40} \mathrm{~K}$. The overall average values of the activity concentration in snuff and cigarette samples were 69.33 and $48.37 \mathrm{~Bq} \mathrm{~kg}^{-1}$ for ${ }^{40} \mathrm{~K}, 17.41$ and 17.52 $\mathrm{Bq} \mathrm{kg}^{-1}$ for ${ }^{238} \mathrm{Uand} 14.55$ and $12.39 \mathrm{~Bq} \mathrm{~kg}^{-1}$ for ${ }^{232} \mathrm{Th}$ respectively. The average values of the absorbed dose rate due to direct exposure to the snuff and cigarette samples were 19.72 and $17.59 \mathrm{nGy} \mathrm{h}^{-1}$ respectively while the average values of effective doses due to daily inhalation of smoke by consumers from one (1) stick of cigarette and one (1) wrap of snuff were 66.62 and $592.32 \mu \mathrm{Sv} \mathrm{yr}^{-1}$ respectively. Similarly, the values of the radium equivalent activity index for the snuff and cigarette samples were 40.95 and $38.95 \mathrm{~Bq} \mathrm{~kg}^{-1}$ respectively while the average excess 
lifetime cancer risk $\left(\mathrm{x} 10^{-3}\right)$ values for daily inhalation of smoke from one (1) stick of cigarette and sniffing of one (1) wrap of snuff were 0.23 and $1.93 \times 10^{-3}$ respectively.

The activity concentrations of the radionuclides detected in the snuff products was a little bit higher than that of the cigarette products. Furthermore, the radioactivity content varies within the same brands of cigarette and also with different brands. The estimations of some radiological impacts were found to be lower than their respective recommended limit. However, the effective dose poses a serious health risk to addicted consumers and passive smokers in the environment when three (3) or more wraps of snuff and one (1) or more packs of cigarette products are consumed daily. The excess lifetime cancer risks values estimated were also much higher than the recommended limits by UNSCEAR (2000). This poses a serious cancer risk and some other radiation injuries to the consumers and passive smokers in the environment.

It can then be concluded that numerous variables such as the geographic region where the tobacco (raw material) is grown, the fertilizer used to cultivate farmlands, the fineness of the tobacco cut, the size and composition of the filter, different manufacturing procedures, age of the products (as manufactured and expiring date are not indicated on the packs of cigarettes) and most especially, sniffing or smoking habits govern the degree of exposure via the pathway of tobacco products.It is therefore recommended that the tobacco leaves should be thoroughly washed before being processed, less radioactive fertilizer should be used to cultivate the farmlands and most important, addicted consumers should seek medical advice.

\section{ACKNOWLEDGEMENTS}

We would like to show our gratitude to the reviewers for their insights. We are immensely grateful for their comments and contribution on the earlier version of the manuscript.

\section{REFERENCE}

Abd EL-Aziz, N., Khater, A. E \& Al-Sewaidan, H. A. 2005. Natural radioactivity content in tobacco.International Congressseries, 1276: 407-408.

Avwiri G.O., Ononugbo C.P \& Nwokeoji I.E. 2014.Radiation hazard indices and excess lifetime cancer risk in soil, sediment and water around mini-okoro/oginigba creek, Port Harcourt, Rivers State, Nigeria. Comprehensive J. Environment and Earth Sciences, 3(1): 38-50. 
Barrera, R \& Werusman, E. W. 1966.Tobacco Science. Nature, 10:157, cited in Martel, E.A, 1974. Radioactivity of tobacco trichomes and insoluble cigarette smoke particles. Nature, 249: 215-217.

Borgerding, M \& Klus, H. 2005. Analysis of complex mixtures-cigarette smoke. Journal of Experimental and Toxicologic Pathology, 57:43-73.

Colangelo, C. H., Huguet, M. R., Palacios, M. A\& Oliveira, A. A. 1992. Levels of ${ }^{210}$ Po in some beverages and in tobacco. J. Radioanalytical and Nuclear Chemistry, 16: 195-202.

Critchley, J. A \& Unal, B. 2003. Health effects associated with smokeless tobacco: a systematic review. Thorax, 58:435-439.

Desalu, O. O., Iseh, K. R., Olokoba, A. B., Salawu, F. K \& Danburam, A. 2010. Smokeless tobaccouse in adult Nigerian population. Journal of Clinical Practice, 13(4):1-6.

Hall, E. J. 2000. Radiobiology for the Radiologist. $5^{\text {th }}$ Edition, Lippincott Williams \& Wilkins, University of Michigan, ISBN: 0781726492, 9780781726498, 588p.

ICRP. 2012. Compendium of dose coefficients based on ICRP publication 60. International Commission on Radiological Protection, ICRP Publication 119, Annex of ICRP 41.

Jibiri, N. N \& Biere, P. E. 2011. Activity concentrations of ${ }^{232} \mathrm{Th},{ }^{226} \mathrm{Ra}$ and ${ }^{40} \mathrm{~K}$ andgamma radiation absorbed dose rate levels infarm soil for the production of different brands ofcigarette tobacco smoked in Nigeria. Iran Journal of Radiation, 8(4):201-206.

Jibiri, N. N \& Fasae, K. P. 2012. Activity concentrations of ${ }^{226} \mathrm{Ra},{ }^{232} \mathrm{Th}$ And ${ }^{40} \mathrm{~K}$ in brands of fertilizers used in Nigeria. Radiation Protection Dosimetry, 148(1):132-137.

Khater, A. E. 2004. Polonium-210 budget in cigarettes.J. Environ. Radioactivity, 71:33- 41.

Landsberger, S., Lara, R \& Landsberger, S. G. 2015. Non-destructive determination of ${ }^{238} \mathrm{U}$, ${ }^{232} \mathrm{Th}$ and ${ }^{40} \mathrm{~K}$ in tobacco and their Implication on radiation dose levels to the human body. Radiation Dosimetry, 167(4):1-3.

Madani, A. H., Jahromi, A S., Dikshit, M \& Bhaduri, M. 2010. Risk assessment of tobacco types and oral cancer. Journal of Pharmacology and Toxicology, 5:9-13.

Martell, E. A. 1974. Radioactivity of tobacco trichomes and insoluble cigarette smoke particles. Nature, 249:215-217.

National Institutes of Health (NIH). 1993. US Department of Health and Human Services (UDHHS), Public Health Service (PHS), National Institutes of Health (NIH) (1993): 
"Smokeless tobacco or health: An international perspective on smoking and tobacco control monograph" National Institutes of Health (NIH) Publication number, 93:34-61.

Papastefanou, C. 2009. Radioactivity of tobacco leaves and radiation dose induced from smoking. International Journal on Environment and Public Health, 6:558-567.

Ponte, L. 1986. Radioactivity: The new-found danger in cigarettes. Reader's Digest, 123-127.

Reinskje, T., Thomas, S.,Ewa, F., Jan van, B., Piet, W \& Antoon, O.2011. Hazardous Compounds in Tobacco Smoke. International J. Environ. Research and Public Health, 8(2):613-628.

Singh, D. R \& Nikelani, S. R 1976. Measurement of polonium activity in Indian tobacco. Health Physics, 31: 393-394.

Skwarzec, B., Struminska, D. I., Ulatowski, J \& Golebiowski, M. 2001a. Determination and distribution of ${ }^{210} \mathrm{Po}$ in tobacco plants from Poland. Journal of Radioanalytical and Nuclear Chemistry, 250 (2): 319-322.

Skwarzec, B., Ulatowski, J., Struminska, D. I \& Borylo, A. 2001b. Inhalation of ${ }^{210} \mathrm{Po}$ and ${ }^{210} \mathrm{~Pb}$ from cigarette smoking in Poland. Journal of Environmental Radioactivity, 57:221-230.

Takizawa, Y., Zhang, L \& Zhao, L. $1994 .{ }^{210} \mathrm{~Pb}$ and ${ }^{210} \mathrm{Po}$ in tobacco with a special focus on estimating the doses to man. J. Radioanalytical and Nuclear Chemistry, 182:119-125.

The Sun Newspaper 2017. Reducing Tobacco Consumption in Nigeria. http://sunnewsonline. com/reducingtobacco-consumption-in-nigeria/.

Thielen, A., Klus, H \& Muller, L. 2008. Tobacco smoke: unraveling a controversial subject. $J$. Experimental and Toxicologic Pathology, 60:141-156, doi: 10.1016/j.etp.2008.01.014.

Tso, T. C., Harley, N \& Alexander, L. T. 1966. Source of lead-210 and polonium-210 in tobacco. Science, 153:880-882.

United Nations Scientific Committee on the Effects of Atomic Radiation (UNSCEAR). 2000. Sources and effects of ionizing radiation. Report presented to general assembly with scientific annexes. V. 1, UN Publication, New York, ISBN: 92-1-142238-5, 653p.

United Nations Scientific Committee on the Effects of Atomic Radiation (UNSCEAR). 2008. Report presented to the general assembly with scientific annexes, Scientific Annexes, V. 2, UN Publication, New York.

Watson, A. P. 1985. Polonium-210 and lead-210 in food and tobacco products: transfer parameters, normal exposure and dose. Nuclear Safety, 26(2):179-191. 
World Health Organization (WHO). 2008. Report on the global tobacco epidemic. MPOWER Package.Geneva, 329p.

Yasser, Y. E \& Khater, A. 2006. Determination of lead-210 in environmental samples using different radioanalytical techniques. J. Radioanalytical and Nuclear Chemistry, 269: 609619. 